\title{
Oğuz Kağan destanında Türklerin lider anlayışı üzerine bazı tespitler
}

\section{Erkan KALAYCI'} APA: Kalaycı, E. (2019). Oğuz Kağan destanında Türklerin lider anlayışı üzerine bazı tespitler.
RumeliDE Dil ve Edebiyat Araştırmaları Dergisi, (14), 198-214. DOI: 10.2900o/rumelide.541012

\section{$\ddot{\mathbf{O} z}$}

Destanlar, içinde yaratıldıkları milletin dünyaya bakış açısını, sahip olduğu inanç ve değerlerini, sosyal yapısını büyük oranda ortaya koyar. Bütün bunlar o toplumun muhayyilesinde olgunlaştırdı̆̆ idealleştirilmiş tipler vasıtasıyla gözler önüne serilir. Atlı- göçebe yaşam tarzını benimseyerek bozkır medeniyetinin bir parçası olan Türkler de sözlü gelenek şiir sanatları içinde yarattıkları destanlardan biri olan Oğuz Kağan Destanında bu algılarını, ideallerini ve beklentilerini toplumun lideri olan Oğuz Kağan’ın kimliğiyle ortaya koymuşlardır. Biz de bu çalışmada Oğuz Kağan Destanı'ndan hareketle atlı-göçebe yaşam tarzının idealleştirilmiş kahramanı olan Oğuz Kağan’ın sosyal psikolojinin verilerinden de istifade etmek suretiyle sosyal statüsünü belirlemeye ve böylelikle atlı-göçebe bir toplumun ideal lider algısının özelliklerini ortaya koymaya çalışacağız. Çalışmamızda yararlanacağımız metinler R. Rahmeti ve W. Bang'ın birlikte yayınladıkları Uygur harfli Oğuz Kağan Destanı ve bazı noktalarda detaya inerek daha fazla ayrıntılı bilgi vermesi nedeniyle Z. Velidi Togan'ın yayınladığı Reşideddin Oğuznamesinin (Camiü’t-Tevarih) tercümesinde yer alan ve Oğuz Kağan destanının İslamiyet sonrasındaki versiyonu olan “Tarih-i Oğuzân ve Türkân” bölümü olacaktır.

Anahtar kelimeler: Oğuz Kağan, destan, kahraman, sosyal statü.

\section{An assesment on the leader perception of Turks in Oghuz Khagan epic}

\begin{abstract}
Epics, generally reflects the worldview, beliefs, values and social structure of the nation in which it was brought to existance. All of these are put forward by the idealised characters whom are brought to maturity in the imagination of the society. Turks -by adopting nomadic life and becoming a part of the steppe civilization- reflected their perceptions, ideals and expectations by the leader Oghuz Khagan who is a hero created in oral-cultural poetry. In this context, the aim of this paper is to determine the social status of Oghuz Khagan, who is an idealised hero of a nomadic culture, with reference to Oghuz Khagan Epic and so that put forward the features of ideal leader perception of a nomadic society. In this paper we will benefit from Oghuz Khagan Epic -written with Uighur alphabet- which is published by R. Rahmeti and W. Bang; and "Tarih-i Oğuzan ve Türkan" which is considered as the post-Islamisation version of the Oghuz Khagan Epic and also a chapter in Rashiduddin's “Cami Al-Tevarih” published by Z. Velidi Togan.
\end{abstract}

Key words: Oghuz Khagan, epic, hero, social status.

$1 \quad$ Arş. Gör. Dr., Kırklareli Üniversitesi, Fen-Edebiyat Fakültesi, Türk Dili ve Edebiyatı Bölümü, Halk Bilimi ABD (Kırklareli/ Türkiye), kalaycierkan@klu.edu.tr, ORCID ID: 0000-0002-9734-7435 [Makale kaylt tarihi: 12.01.2019-kabul tarihi:12.03.2019; DOI: 10.2900o/rumelide. 541012] 


\section{Giriş}

Destan, ürünü oldukları toplumun dünya görüşünü, değer yargılarını, sosyal yapılarının yansımalarını içinde barındırabilen bir anlatı türüdür. Oğuz Kağan Destanında da atlı- göçebe yaşam tarzını benimseyerek bozkır medeniyet dairesinin bir parçası olan Türklerin dünya görüşleri, değer yargıları ve ideal bir yöneticiden beklentileri Oğuz Kağan'ın idealleştirilmiş kimliği vasıtasıyla ortaya koyulmaktadir.

M.Ö. I. binde Türk destan edebiyatının teşekkülünden (Yıldırım 1998b: 150) bu yana geçen süreçte pek çok destan kahramanı yaratılmıştır ve bu kahramanların hepsi de toplumun idealize ettiği pek çok değerin temsilcisidirler. Oğuz Kağan da içinden çıtı̆̆ı Türk toplumunun var olma mücadelesinin ve töresinin şekillendirdiği bir liderdir. Çünkü sosyal kurallar davranışa yol gösterirler ve toplumlar ortak bir çerçeve oluşturarak bireylerin hareketlerini bunlara göre yönlendirmelerini sağlarlar (Arkonaç, 2001: 210-211).

Yeryüzünün ve kainatın oluşumuna, kaostan kozmosa dönüşüm sürecine dair geleneksel dünya görüşlerinin ilk verileri olarak tanımlanabilecek olan mitlerden sonra ve çoğunlukla onların gölgesini ve çizgilerini taşıyan (Çobanoğlu, 2011: 16) destanlar adı ne olursa ne olsun bir kahraman etrafında bu verilere ek olarak -birer tarihi belge olmamak kaydıyla- toplumun tarihini ve idealize ettiği unsurları aktarirlar.

Oğuz Kağan Destanının elimizde bulunan iki nüshası Türk toplumunun farklı dönemlerini yansıtmakla beraber genel olarak benzer bir çerçeve içerisinde Oğuz Kağan'ın kahramanlık serüvenini ortaya koymaktadır. ${ }^{2}$ Ancak her iki metinde de Türk toplumunun lideri konumunda bulunan Oğuz Kağan'ı toplumun kahramanı haline getiren bir takım özellikleri ön plana çlkmaktadır. İki metini birden kullanmak birbirlerinin boş bıraktıkları bazı noktalarda bütünlüklü bir bakış açısıyla Oğuz Türklerinin kahramanlık ve liderlik algılarına dair daha fazla veri sunmaktadır.

Türk toplumunun lideri olarak öne çıkan bir figürün sıradan insanlar ile aynı özellikleri taşıması elbette her şeyden önce bir kahraman etrafında şekillenen destan anlayışının tabiatına aykırı bir durumdur. Bu nedenle destan kahramanı o toplumun muhayyilesinde yaşattığı ve sözlü gelenek içerisinde olgunlaştırarak idealize ettiği bir takım özelliklere sahip olmalı ve sosyal statüsü farklı olmalıdır (Trepalov, 1995: 35-48). Oğuz Kağan Destanı bağlamında bu özellikleri şöyle sıralamak mümkündür:

\section{Tanrisal Köken}

2.Fiziksel Yeterlilik

3.Liderlik Özellikleri

4.İktidar’n Soya Aktarımı ya da İstikrar

\footnotetext{
2 Oğuz Kağan Destanı’nın her iki versiyonu üzerinde yapılmış pek çok çalışma mevcuttur. Bunları burada zikretmek ve her iki versiyon üzerinde yapılmış çalışmaların genel bir tarihçesini vermek çalıșmamızın sınırlarını aşacağından burada değinmedik. Ancak bu konuyla ilgili olarak bakını: (Bars, 2008). Oğuz Türklerinin destani mahiyette ortaya koyduğu eserler hakkında genel bilgi için bakınız: (Sümer, 1960).
} 
Yukarıda sıraladığımız bütün bu özellikler bize destanı yaratan atlı-göçebe Türk toplumunun kahramanının sosyal statüsünü vermektedir. Bunlardan ilki olan ve çok daha büyük bir önem arz eden Tanrısal Köken'le başlamak yerinde olacaktır.

\section{Tanrısal köken}

Oğuz Kağan karizmatik bir liderdir. Yunanca kökenli "karizma" kavramı; "ihsan edilmiş, bağışlanmış" anlamına gelmektedir ve günümüzde "maşallah" sözünün sekülerleştirilmiş şekli gibi durmaktadır. Çünkü maşallah, "Allah'ın dilediği” demektir (Göka, 2009: 75). Türklerde liderlik makamı, her şeyin yaratıcısı olan Gök Tanrı tarafından kağana bahşedilen "kut"la elde edilmektedir ve bu nedenle de Tanrısal kökenli yani uhrevidir (Göka, 2009: 99-101).

Türklerin, elimizde bulunan ilk tarihi vesikalarından biri olan Göktürk Yazıtlarından başlayarak Osmanlı Türklerine kadar giden süreçte, ülkenin ya da milletin lideri konumunda olan yöneticide bir takım Tanrısal vasıflar bulunduğuna inanılmaktadır. İslamiyet öncesinde de var olan bu anlayış İslamiyet'le beraber sadece yeni dinin terminolojisine uygun olacak halde yenilenmiştir. Osmanl dönemindeki "es-sultan zıllullahi fi'l-arz" (Sultan Allah’ın yeryüzündeki gölgesidir) anlayışının ilk örneğini Göktürk yazıtlarında da görmek mümkündür:

KT G1 Tengri teg Tengride bolmış Türük Bilge Kağan, bu ödke olurtum. (Tekin, 2003: 34).

Kendi iradesi ile olan Tanrı gibi, ben de, o Tanrı'nın iradesi ile Kağan olan Türk Bilge Kağan’ım. Bu zamanda (budun üzerine kağan) oturdum (Yıldırım, 1998a: 107).

Bu cümlelerden çıarılacak tek sonuç daha önce de değindiğimiz gibi Türklerde kağanlığın ya da hükümdarlığın Tanrısal bir takım hususiyetleri kendisinde barındırdığı inancının hâkim olduğudur. Oğuz Kağan da bu özelliklere doğumundan itibaren sahip olduğunu pek çok vasitayla göstermiştir.

Tanrı iradesi ile ileride hükümdar olacak olan Oğuz Kağan'ın doğumu bir takım olağanüstülüklerle gerçekleşir. Uygur harfli versiyonda Oğuz'un doğumu anlatılırken “Yine günlerden bir gün Ay Kağan’ın gözü parladı ve... bir erkek çocuk doğurdu” (Bang ve Rahmeti, 1936: 11) ifadesi kullanılır. Ay Kağan’ın gözünün parlaması İslamiyet'le beraber toplumda kabul gören "Allah'ın nurunun yüzde tecelli etmesi” anlayışının İslamiyet öncesindeki halidir. Ay Kağan'ın gözünün parlaması tanrısallığa bir işarettir ve parlayan o ışık Tanrının Oğuz Kağan'a hükümdar olabilmesi için doğarken bahşettiği kutun bir işaretidir. Mo-tun'dan Kültigin'e kadar pek çok Türk Kağan’ı "kutlu”, "kutalmış” olduklarını kendileri ifade etmişlerdir. Oğuz Kağan da, daha doğumunda bu “kut”a nail olmaktadır (Duymaz, 2007: 52). Buna benzer bir durumun varlı̆̆ına Moğolların Gizli Tarihi'nde de rastlanmaktadır. 3 Cengiz Han'ın atalarından Alan Ko'a babasız olarak dünyaya getirdiği üç çocuğun nasıl olduğunu Dobun-Mergen'den olan ve ondan şüphe eden çocuklarına şöyle anlatır:

Fakat her gece sarışın bir adam, evin bacasından sızan ışık vasıtasiyle girerek karnımı okşuyor ve onun nuru vücuduma geçiyordu. Çıkarken de güneş veya ayın nurları üzerinden sarı bir köpek gibi sürünerek çıkıordu. Siz nasıl böyle düşünmeden konuşuyorsunuz. Bu hadise üzerinden fikir yürütülürse, onların Tanrı oğlu oldukları meydana çıkar. Kardeşlerinizi kara başlı insanlarla mukayese ederek nasıl öyle konuşabiliyorsunuz? Onlar bütün insanların hanı oldukları zaman adi halk bütün hakikatı anlayacaktır (Temir, 2010: 8).

Yukarıdaki satırlarda Alan Ko'a’nın anlattıkları babasız olarak dünyaya getirdiği üç çocuğun tanrı oğlu olduklarını açıkça belirtmesiyle birlikte tamamen aydınlığa kavuşmaktadır. Bir ışık huzmesi olarak

3 Ayrıntılı bilgi için bkz: (Ögel, 2003: 131). 
çadırın açıklı̆̆ından içeri giren tanrısal ışık Alan Ko'a'nın gebeliğine yol açmış ve Alan Ko’a tanrının kutuyla kutsadığı üç oğul doğurmuştur ki onlar bu kut sayesinde insanlara kağan olacaklardır. Dolayısıyla bu durumun benzer bir kültür sahası içinde yaratılan Oğuz Kağan Destanı için de geçerli olduğunu belirtmemiz gerekir. Oğuz Kağan da tıpkı kendi gibi atlı-göçebe bir halkın lideri olan Çengiz Han'a benzer şekilde Tanrısal bir ışı̆̆ın yayılması şeklinde tezahür eden kutu almıştır ve bu kut onu kağanlığa taşıyacaktır.

Oğuz Kağan destanının İslami versiyonu olan Tarih-i Oğuzân ve Türkân'da Oğuz Kağan'ın doğumuyla ilgili bu tarz olağanüstülükler yoktur ancak İslamiyet’in getirdiği kutsiyet anlayışı kendisini başka bir hüviyet altında göstermektedir. Reşideddin'in aktardığı rivayete göre Nuh Peygamber yeryüzünü oğulları arasında paylaştırdığında oğlu Yafes'e Türkistan ve etrafını verir. Türklerin Olcay Han dedikleri Yafes’in Dib Yavku adında bir oğlu olur ve hükümdarlık ona geçer. Dib Yavku'nun da Kara Han, Or-Han, Kür Han ve Küz Han adında dört oğlu vardır. Bunlardan Oğuz Han'ın babası olan Kara Han tahtın varisidir. Dolayısıyla Oğuz Han'ın soyu Nuh Peygamber'e kadar giden ve Tanrı'nın dünya üzerinde hâkimiyeti elleriyle verdiği bir soya dayanmaktadır. Oğuz Han doğumundan sonraki eylemleriyle de soydan gelen Tanrısallığını pekiştirecektir.

Oğuz Kağan'ın doğumunun ardından sergilediği davranışlar da onun olağanüstülüğünün habercisi gibidir. Uygur harfli Oğuz Kağan Destanında Oğuz’un doğduktan sonraki hali şöyle anlatılır:

Bu çocuk anasının göğsünden ilk sütü emdi ve bir daha emmedi. Çiğ et çorba ve şarap istedi. Dile gelmeğe başladı; kırk gün sonra büyüdü, yürüdü ve oynadı (Bang ve Rahmeti, 1936: 11).

Hayata atılmanın ilk şartı annenin memesinden kopuştur. Oğuz Kağan ilk eylem olarak bu kopuşu başarır. Arkadan ataerkil toplumun biçimlendirdiği erkeksi bir davranışla göçebenin dünyasında önemli bir yeri olan "çiğ eti” yer ve "şarabı" içer. Böylece Oğuz Kağan aileye bağımlılık sürecini normal bir insanın gerçekleştiremeyeceği kadar kısa bir sürede tamamlamıştır (Özcan, 2003: 77).

Oğuz Kağan’ın sergilediği bu davranışların eski Türk diniyle alakası olduğunu düşünen araştırmacılar da vardır. Bunlardan biri olan Fuzuli Bayat, Oğuz Kağan'ın annesini bir defa emip bir daha emmemesine yönelik olarak şu değerlendirmeyi yapar:

Oğuz Kağan destanında Oğuz bir defa süt emip bir daha emmediği gibi Şaman adayı da albısın döşünden bir defa emip ikrahla başını çevirir. Şaman buna göre de bazen albısın döşünü değil, bir kaba sağıp çayla karıştırdığı sütünü içer. Şamana döş yahut süt veren ruhlar daha sonradan onun kamlık yaptığı ruhlar, bazen de yardımcıları olurlar. Oğuz Kağan destanında kahramanın döş emmesi, hiç kuşkusuz epik kurala uygun bir biçime dönüştürüldüğünden Şaman dünya görüşü ile ilişkili bazı kodlar anlam kayması geçirmiştir (Bayat, 2006: 141-142).

Bu noktalardan hareketle Oğuz’un anne sütünü bir defa emip sonra bir daha emmemesi hem göçebe hayat tarzına göre Oğuz’un hemen hayata atılma hızını göstermekte hem de İslam öncesi eski Türk dinine göre Oğuz'un bir şaman gibi Tanrı ile rabıtasına işaret etmektedir. Ayrıca göçebe toplumun kahramanının gelişip serpilmesini bekleyecek ne vakti ne de sabrı vardır. Dahası kahramana ulusun başına musallat olan musibetleri defetmek için şiddetle ihtiyaç vardır ve kahraman adeta bu ihtiyacı gidermek için doğacaktır. Nitekim Manas destanında da Manas daha beşikteyken dile gelerek şunları söyler:

Ak sakallı ateke Cakıp Han,

Müslüman yolunu açacağım,

Kafirin malını saçacağım, 
Kafiri sürüp çıarı,

Müslümana necat salacağım (Ylldız, 1995: 539).

Burada da görüldüğü gibi kahraman daha doğumundan itibaren hedefe kilitlenmiş bir şekilde kutsal amacı hayata geçirmek için doğar.

Reşideddin Oğuznamesinde Oğuz’un ilk sütü emmesiyle ilgili bölüm İslami unsurlarla bezenmiştir. Oğuz, annesi ve babası Müslüman olmadı̆̆ halde Müslüman olarak doğar. Annesini üç gün üç gece boyunca emmez. Çocuğun yaşamından artık ümidini kesen annesi üç gün üç gece boyunca oğlunun kendisine "Ĕ̆er sütünü emmemi istiyorsan, biricik Tanrıy ikrar ve itiraf et; üzerine olan hakkını oluğu gibi farz bil" (Togan, 1972: 17) dediğini görür ve bunu hiç kimseye anlatmadan gizlice Tanrıya iman eder ve sütünün çocuğa yaraması için yalvarır. Bunun üzerine Oğuz hemen annesini emmeye başlar. Çocuğun varlığındaki asaletin farkına varan babası şöyle der:

\section{"bizim kavim ve uruğumuzda bundan daha güzel bir çocuk dünyaya gelmemiștir... Çocuk bir yıl sonra [aynı İsa peygamberinki gibi] dili açılıp konuşmaya başladı ve ben bir otağda doğduğum için adımı Oğuz koymak gerekir"(Togan, 1972: 18).}

Uygur harfli versiyonda Oğuz’un adının nereden geldiği ve onun adını kimin koyduğuna dair bir bilgi yoktur ancak Oğuz’un bu kadar küçük bir yaşta dile gelmesi ve kendi kendine ad vermesi onun Tanrısallığını ortaya koymak açısından büyük önem arz etmektedir. Oğuz Türklerinin destanî mahiyetteki bir başka eseri olan Dede Korkut Kitabı'nı hatırlayacak olursak bu durum daha iyi anlaşlacaktır. Tanrının gönlüne ilham ettiği, gaybten haber veren, Oğuz’un tamam bilicisi Dede Korkut, Dirse Han Oğlu Boğaç Han ve Kam Büre Oğlu Bamsı Beyrek Boyunda kahramanlara ad verir. Boyun en yaşlı ve kutlu kişisi tarafından gerçekleştirilen ad koyma işlemi burada doğrudan Oğuz tarafından gerçekleştirilmektedir. Dahası, Dede Korkut Kitabında genellikle baş kesip kan döktükten sonra alınan adın burada Oğuz tarafından daha çok küçük bir yaşta verilmesi onun ileride yapacağı kahramanlıkların da adeta çok önceden verilmiş bir teminatı gibidir.

Kahramanın bir ad taşıması neden gereklidir? Bir ismin kahramana uygunluğu, bir kişinin, nitelik bakımından başka bir kişiden farklı eylemleri gerçekleştirebilmesi anlamına gelir. Epik anlatım, bir başka deyişle, kahramanın yetenekleri ve sınırlılıkları arasındaki düzenlemeler serisidir. Bir kahraman olarak onun hayatı, adının taşıdığı anlamın ifade edilmesine bağlıdır. Çünkü o, alelâde bir varlıktan farklı olarak, ayırt edici özel bir şeyi başarabilme gücüne sahiptir ve bir tanrıdan farklı olarak da, geçmiş başarıları yoktur, kahraman, adının taşıdığı anlamı başlangıçta ortaya çıkarmalı ve ispatlamalıdır (Greene, 1998: 132).

Uygur harfli Oğuz Kağan Destanında Oğuz’un büyük bir hızla büyümesi ve hızla erginlenmesi4 ve kendisini ispatlamasının ardından olağanüstü iki kızla evlenmesi gerçekleşir. Oğuz’un bu iki evliliği ve bu evliliklerinden doğan çocuklarının adları da onun tanrısallığı ve ileride gerçekleştireceği cihan hâkimiyetine işaret eder niteliktedir.

Oğuz'un ilk eşiyle karşılaşması şu şekilde anlatılmaktadır: Yine günlerden bir gün Oğuz Kağan bir yerde Tanrı'ya yalvarmakta idi. Karanlık bastı. Gökten bir gök ışık indi. Güneşten ve aydan daha parlaktı (Bang ve Rahmeti, 1936: 14). Oğuz bu ışığın indiği yöne gittiğinde ışığın içinden çok güzel bir kız çıkar. Ŏ̆uz kızı çok beğenir ve ondan dileğini alır. Kız gebe kalır ve günler ve gecelerden sonra gözü parlayarak üç

Oğuz’un erginlenmesi ve kendini ispatlaması meselesine daha ayrıntılı olarak “Oğuz’un Fiziksel Yeterliliği” başlığı altında değinilecektir. 
erkek evlat doğurur. Bu çocuklara Kün, Ay ve Yultuz adını koyarlar. Daha sonra Oğuz Kağan bir ava çıkar ve göl ortasında yalnız bir ağaç görür. Oraya gidip baktığında ağacın kovuğunda yalnız başına oturan bir kız görür. Bu kızı gören Oğuz’un aklı başından gider ve ondan da dileğini alır. Günler ve gecelerden sonra bu kızın da gözleri parlar ve üç erkek evlat dünyaya getirir. Bu çocuklara da Kök, Tağ ve Tengiz adını verirler. Oğuz’un bu evlilikleriyle ilgili olarak dikkati çeken noktalar öncelikle eşleriyle karşllaşma şekilleri ve daha sonra da her iki eşinin de doğum sırasında gözlerinin parlamasıdır.

Oğuz’un ilk eşinin bizzat Gök Tanrı tarafından gönderildiği açıktır. Bu kız bir ışık huzmesi içerisinde Oğuz’un Tanrıya dua ettiği bir sırada yeryüzüne inmiş̧ir ki daha önce ışı̆̆ın Türk düşünce sistemi içerisinde Tanrısallığa bir işaret olduğunu söylemiştik. Oğuz’un ilk eşinin doğum esnasında tıpkı Ay Kağan gibi gözlerinin parlaması da doğan çocukların ileride kendilerini hükümdar yapacak olan Tanrı kutuna sahip oluşlarına işarettir. Çocukların adları ise Oğuz'un kurmaya çalıştığı düzenin ilk aşamasının tamamlandığını gösterir niteliktedir. Nitekim Oğuz düzeni öncelikle kainattan başlayarak kurar. Bu nedenle gökten bir kız gelmiş ve Gün, Ay ve Yıldız hanlar bu kızdan doğmuş ve göğün üç unsuru bu suretle bu kızdan doğan çocuklarla tamamlanmıştır (Ögel, 2003: 140). Bahaeddin Ögel'in (2003: 140) Türk mitolojik sisteminde bulunduğunu belirttiği, kainat ve özellikle uzaydan oluşan "büyük kozmos" birliği bu ilk evlilik ve bu evlilikten doğan üç çocukla sağlanmıştır.

Ögel (2003: 140) Oğuz’un ağaç kovuğundan gelen ikinci eşinin ise Iduk Yer-Sub tarafından gönderildiği kanaatindedir. Bu ikinci evlilikten olan Gök, Dağ ve Deniz Han'lar ise yeryüzü ve Dünyayı içine alan "küçük kozmos" birliğini meydana getirmektedir. Yine Oğuz’un ilk eşinde olduğu gibi ikinci eşinde de çocukların doğumları sırasında kızın gözlerinin parlaması bu çocuklarda da ileride hükümdar olabilmelerini sağlayacak Tanrı kutunun kendilerine verilmiş olduğunun ispatıdır. Bir anlamda bu evliliklerle Oğuz öncelikle Tanrı düzeninin yeryüzündeki sağlayıcısı olma rolünün bir aşaması olan kozmos birliğini sağlamıştır. Bu birliğin sağlanmasının hemen ardından sıra bozkır birliğini sağlamaya gelecektir ki bunu da cihan hâkimiyeti takip edecektir.

Oğuz Kağan Destanının İslami versiyonu olan "Tarih-i Oğuzân ve Türkân”da ise Oğuz'un evlenmesi Uygur Harfli versiyona nazaran olağanüstülüklerden sıyrılmış ve daha gerçekçi bir tablo çizmektedir. Oğuz babası Kara Han tarafından önce amcası Küz Han'ın kızıyla evlendirilir ancak dindar bir Müslüman olan Oğuz bu kıza Tanrıya iman etmesini söyler. Kız bunu kabul etmeyince Oğuz ondan soğur ve hiç yanaşmaz. Bu hali gören babası ona bu sefer de diğer amcası Kür Han'ın kızını alır ancak Oğuz aynı şeyi bu kızdan da ister. Bu kız da Oğuz’un dileğini kabul etmeyince Oğuz bu kızdan da soğur. Oğuz'un her iki kızdan da nefret ettiğini gören babası bu sefer de ona amcası Or-Han'ın kızını ister. Oğuz da tesadüfen bu kızı cariyelerle birlikte çamaşır yıkarken görür ve ona niyetini açıklar. Eğer Müslüman olursa onu eşliğe kabul edeceğini söyler. Kız bu isteğini kabul eder ve Oğuz onu kendisine eş olarak alır. Oğuz'un bu kızı çok sevmesi üzerine diğer iki eşi durumu babası Kara Han'a anlatır ve Oğuz'la babası ve amcaları arasında 75 yll sürecek bir savaş başlar.

Yukarıda görüldüğü gibi Oğuz Kağan destanının İslami versiyonunda Uygur Harfli versiyondaki gibi doğrudan Tanrının gönderdiği iki kızla evlilik söz konusu değildir. Burada daha çok ağır basan Oğuz’un İslamiyet'i benimsemiş göçebe toplumun "dindar lider" ideallerine uygun olarak kendisine Müslüman bir eş aramasıdır. Her zaman dindar bir tablo çizen Oğuz burada Türk toplumunun ideallerine ama daha önemlisi tıpkı Uygur harfli versiyonda ağır basan eski Türk dininde olduğu gibi Tanrının uygun gördüğü şekilde bir eş seçimi yapmak zorundadır. Çünkü doğuştan Müslüman olan kağan için esas olan öncelikle kendi gibi iman etmiş bir eş bulmaktır. Nitekim bir toy sırasında diğer iki gelin daha güzel olduğu halde Oğuz'un neden son eşini daha çok sevdiğine anlam veremeyen babası bunu gelinlerine sorduğunda, 
Oğuz’un son eşini Müslüman olduğu için daha çok sevdiğini öğrenir. Bu yüzden babası ve amcalarıyla 75 yıl savaşan Oğuz savaştan en sonunda galibiyetle çlkar ve Tanrı'ya iman etmeyen soydaşlarını sürer. Burada esas olan önce İslam'ın ulus içinde kökleşmesini sağlamak ve ondan sonra cihan hâkimiyetine soyunmaktır. Böylelikle Müslümanlığı yeni yeni benimseyen göçebe Türkler ideallerindeki hükümdar tipinin öncelikle Allah için gaza etmekle yükümlü olduğunu ortaya koymaktadır. Allah için gaza eden hükümdar Allah'ın getirdiği yeni düzenin yayıcısı olacağından iktidarı da Allah’ın desteğini kazanmış olacaktır.

Bu düşüncenin kökeninin İslam öncesi Türklerin dünya algısının bir devamı olduğunu söyleyebiliriz. Erol Göka (2011: 196) Türklerin eski dünya algısına göre kendilerini dünyanın merkezine, Gök Tanının temsilcisi olan kağanın da dünyanın yönetimine yerleştirildiğini düşündüklerini ileri sürmektedir. Dolayısıyla Türkler dört bir yandan çevrilmiş olduklarını düşünerek var olma mücadelelerinin bir sonucu olarak nizam-ı âlem ülküsünü benimsemiş (Göka, 2009: 272) ve Tanrı'dan kut almış kağanı takip ederek mutlak düzeni dünya üzerinde yayma ülküsünü benimsemiştir. Türk toplumunun "toplulukçu" bir kültüre sahip olması ve benliği aşan varlıklara karşı gösterdiği sadakat ve bağlllık (Kağıtçıbaşı 2007: 24) bu bağlamda söz konusu idealleri gerçekleştirme noktasında Tanrısal kökeniyle Oğuz Kağan'ın şahsında lidere yönelmektedir. Dolayısıyla da bu temeller üzerinde İslamiyet öncesinin kut anlayışı İslamiyet'le birlikte "es-sultan zıllullahi fi'l-arz"a dönüşmüş ve aynı idealler kültürel süreklilik içerisinde aktarılmıştır.

\section{Fiziksel yeterlilik}

Bozkır toplumunda kağan olacak kişinin Tanrısal bir kökene sahip olmasının yanında iktidarını korumak ve otoritesini sağlamlaştırmak için fiziksel güce de sahip olması gerekmektedir. Tanrısal köken ancak fiziksel güçle birleştiğinde iktidara giden yolu açacaktır.

Oğuz Kağan'ın tasvirindeki detaylar onun fiziksel gücüne işaret etmektedir. Oğuz adeta bozkır medeniyetinin algısına göre doğada gücüyle öne çımış olan hayvanların her birinin en güçlü yönlerini kendi bedeninde toplamıştır:

Ayakları öküz ayağı gibi, beli kurt beli gibi, omuzları samur omzu gibi, göğsü ayı göğsü gibi idi. Vücudu baştan aşağı tüylü idi. (Bang ve Rahmeti, 1936: 11).

Oğuz baştan ayağa, doğa ile iç içe yaşayan bozkır insanının zihninde yer alan kuvvet alametleriyle donatılmıştır. Gücü ve dayanıklılı̆̆ıyla ön plana çıkan öküzün ayakları Oğuz’un yeryüzünde sağlam duruşunu sağlayacaktır. Cüssesinin verdiği heybetle öne çlkan ayının göğsü gibi bir göğse sahip olmak da Oğuz’un heybetini arttıracaktır. Böyle bir göğüs ise ancak samurunki gibi parlak ve kıvrak omuzlarla etkin bir silaha dönüşecektir. Avcılığı ve asaletiyle Türkün estetik algısında her zaman yer etmiş olan kurt ise avının peşinden hızla gitmesini sağlayan bacakları taşıyan beliyle Oğuz'a kuvvet verecektir. Son olarak da Oğuz’un kıllarla kaplı vücudu sanki bir örgü zırhla kaplanmış bir savaş̧̧ı imajı vermektedir. Bütün bu özellikleriyle Oğuz bizzat doğa tarafından savaş için doğuştan donatılmış gibi bir görünümü sergiler. Nitekim bu hazırlığı doğuştan yapılmış olan Oğuz Kağan destanın bakış açısına göre bir zayıflık olarak kabul edilebilecek ve böylesine bir donanıma yakışmayacak olan çocukluğu hızla geride bırakarak kendisini ispatlamasına firsat tanıyacak olan ilk mücadeleye geçecektir.

Reşideddin Oğuznamesinde Oğuz’un beden tasvirinde olağanüstülüklere rastlanmamaktadır ancak Uygur harfli metinde bizzat Gök Tanrı'nın inayetiyle doğanın kendisine sunduğu silahlarla donanan 
Oğuz Kağan’ın yerine kuvvetli imanı sayesinde her türlü silahı ustalıkla kullanabilen bir İslami Oğuz Kağan karşımıza çıkmaktadır:

Oğuz Çocukluğunda ve büyüme çağında, ergin oluncaya kadar daima Tanrıyı anıp ona şükrederdi. Her firsatta ister uykuda, ister uyanık halde, yaratıcı Tanrıyı muhakkak anardı. Ona Tanrının nurlu feyzi erişti. Her türlü bilim ve hünerde, ok atmada, kargı kullanmada, kılıç çalmada ve bilgi hususuna aleme ün olacak şekilde gelişme gösterdi. Babası ona amcası Küz Han’ın kızını nişanladı (Togan, 1972: 18).

Görüldüğü gibi Oğuz’un fiziksel yeterliliği tamamen inanan bir kul olması nedeniyle Tanrının kendisine bahşettiği nurlu feyzden ileri gelmektedir. Biraz ileride tekrar ele alacağımız Uygur harfli versiyonda olduğu gibi Oğuz’un fiziksel yeterliliğini sınayacak tehlikeli bir mücadele burada söz konusu değildir. Zaten İslam inancına göre şekillenmiş bir anlayışa göre Tanrının nurlu feyzinin eriştiği bir kahramanın gücünü hemen sınamaya gerek yoktur. Oğuz'un yeterliliği çok daha sonra inancı için babası ve amcalarıyla yapmak zorunda olduğu 75 yll süren ve galibiyetle çıtı̆̆̆ savaşta sınanmaktadır ki İslam için gaza eden ve nurlu bir feyz ile donatılmış Oğuz'un böyle bir savaşta yenilgi görmesi mümkün değildir.

Uygur harfli Oğuz Kağan Destanında annesinden, ileride girişeceği mücadeleler için tamamen donatılmış olarak doğan Oğuz atlı göçebe toplumun en büyük serveti olan at sürülerine ve halka musallat olan bir gergedan ile yapacağı ilk savaşta gücünü deneyecek ve erginliğe ulaştığını ispat etmeye çalışacaktır. Oğuz’un bu büyük mücadelesini vereceği yer avları ve kuşları bol bir orman olarak anlatılmaktadır. Bu ormanın içinde de büyük bir gergedan vardır. Cesur bir adam olan Oğuz Kağan da halka ve havyalara zulüm eden bu canavarı avlamak için harekete geçer. Kılıç, kalkan ve yayını alan Oğuz kurnazca davranarak öncelikle canavarı kendi belirlediği bir savaş alanına çekmek için uğraşır (Aça, 2009: 71). Ardından olaylar şu şekilde gelişir:

Kargı, yay, ok, kılıç ve kalkanla ava gitti. Bir geyik ele geçirdi, onu söğüt dalı ile bir ağaca başladı ve gitti. Sonra sabah oldu. Tan ağarırken yine geldi ve gördü ki: gergedan geyiği almış. Sonra Oğuz Kağan bir ayı tuttu; onu altın kuşağı ile ağaca bağladı, gitti. Yine sabah oldu. Tan ağarırken yine geldi ve gördü ki: gergedan ayıyı da almış. Bu sefer o ağacın dibinde (kendisi) durdu. Gergedan geldi ve başı ile Oğuz'un kalkanına vurdu. Oğuz kargı ile gergedanın başına vurdu ve onu öldürdü. Kılıcı ile başını kesti, aldı gitti. (Bang ve Rahmeti, 1936: 11-13).

Oğuz öncelikle zekâsını ve kurnazlığını kullanarak savaşı kendi belirlediği bir alana çekebilmek için kurnazca hareket eder ve avladığı hayvanlar yardımıyla canavarı oraya dadandırarak tuzağa düşürür. Oğuz hızı ve gücüyle tanınan geyik, ayı gibi hayvanları kolayca bu canavara yem ederken hem kendi gücünü göstermekte hem de karşısında bu hayvanları bile yiyebilecek kadar büyük bir canavar bulunduğunu göstererek sonunda kazanacağı zaferin büyüklüğünü pekiştirecektir. Öldürülen gergedandan bahsederken "Bir ala doğan gergedanın bağırsaklarını yemektedir" (Bang ve Rahmeti, 1936: 13) ifadesiyle o güçlü hayvanı Oğuz Kağan'ın ne hale getirdiği ve o yenilmez sanılan yaratığın bedeninin artık kuşlara yem olduğu dile getirilerek küçümsenmektedir. Bu daha sonra Oğuz Kağan’a karşı gelecek, onunla mücadele edecek olan düşmanların akıbetine bir örnek teşkil etmektedir (Güven, 2003: 86).

Oğuz'un bu canavar karşısında almış olduğu galibiyet ise onun hem erginliğe ulaştığının hem de kağanlık yapabileceğinin göstergesidir. Destan kahramanı her zaman ona muhtaç olan ve bir an önce kağan olarak tahta çıkmasını bekleyen bir toplumun üyesidir. Onun bu zaferi kağanlık için gerekli fiziksel güce sahip olduğunun göstergesidir ki bu Dede Korkut Hikâyelerindeki Dirse Han Oğlu Boğaç Han Boyu'na büyük benzerlik göstermektedir. Boğaç da benzer bir şekilde güçlü bir boğayı tıpkı Oğuz 
Kağan gibi hem gücünü hem de zekâsını kullanarak yener. Daha sonra Dede Korkut Boğaç’ı alıp babası Dirse Han'ın huzuruna çıkarır ve "Hey Dirse Han beglik vergil bu oğlana taht virgil erdemlidür” (Ergin, 2011: 82) diyerek Boğaç'ın artık beylik edebilecek olgunluğa eriştiğini gösterir. Bu dövüş çocuğun kendini ispatladığı ve ergenliğe adımını attığı bir geçiştir. Bir hayvanı öldüren Boğaç hem kendini dişilere ispatlayarak evlenmeye hak kazanmış hem de bir ad kazanmıştır. "Boğaç" bir boğayı yenerek onun kişiliğini de kazanmış ve küçük boğa olmuştur (Roux, 2005: 263-271). Oğuz Kağan destanında da Oğuz'un bu canavarı öldürdükten hemen sonra kendine iki eş alması ve daha sonra da Kağan olarak ulusa seslenmesi aynı mantığın geçmişten beri atlı-göçebe kültürde hâkim olduğunu göstermektedir. Dolayısıyla bir kahramana kağanlık/liderlik statüsünün verilmesi onun fiziksel açıdan olgunluğa erişmesi ve bunun yanında zekâsını da kullanması ile mümkün olmaktadır.

\section{Liderlik özellikleri}

Oğuz'un erginliğe ulaşması ve bunun doğal sonucu olarak evlenmesinin ardından kağanlığa yükselişi gelmektedir. Uygur harfli versiyonda halkının başına musallat olan bir canavarı defetmesiyle kağanlığa layık olduğunu gösteren Oğuz, Dede Korkut Kitabından alışık olduğumuz bir şekilde toy düzenleyerek halkını etrafına toplar. Toylar ve bu toylarda verilen ikramlar kağanın halk gözündeki konumunu sağlamlaştırmaktadır. Türklerin düşüncesinde kağanın asli görevlerinden biri halkını beslemektir. Bu anlayışın örneklerine Bilge kağan yazıtında rastlamak mümkündür:

Babam (D 14) hakan vefat ettiğinde ben sekiz yaşımda kaldım. O zamanki töreye göre amcam Hakan olarak tahta oturdu. Tahta oturup Türk halkını yeniden düzenledi ve yeniden besleyip doyurdu. Yoksulu zengin kıldı, azı çok kıldı (Tekin, 2003: 67).

Yukarıda nakledilen bu satırlar aslında Türk toplumunun devletten ve Kağan’dan beklediklerinin neler olduğunu göstermektedir. Devletten ve onun temsilcisi olan kağandan koruyuculuk beklenir. Devletin koruyucu ve güven verici özellikleri onu aileye, lideri babaya benzeterek patrimonyal (ülke çapında siyasal iktidarın "baba" otoritesiyle özdeş görülmesi (Göka, 2009: 118) kılmaktadır ama her şeye gücü yeten anlamındaki "kerim" ve "baba" devlet anlayışı bundan daha ziyade Gök Tanrı inancıyla bağlantılıdır, yani dinseldir (Göka, 2006: 78-81).

Türklerin kağandan bekledikleri bu babalık tutumunu Osman Turan “han-ı yağma” kültürüyle izah eder:

“Türk kağan ve sultanlarının, yabgu ve meliklerinin, Oğuz töresine ve onun tayin ettiği hukuki kaidelere göre beylere ve devlet adamlarına, halka umumi ziyafet vermeleri ve bu esnada sofra ve saray eşyasını yağma ettirmeleri babalık sıfat ve vazifesinin icabı bir anane idi” (Turan, 2003: 102).

Bu anlayışın izdüşümünü Oğuzların destanî mahiyetteki bir başka eseri olan Dede Korkut Kitabı’nda bulmak mümkündür. Kitapta yer alan hemen her boy bir toy sahnesiyle başlamaktadır. Dağ gibi et yığdırılıp göl gibi kımız sağdırılmaktadır ve halk hanlar hanı Bayındır Han'ın sohbetine bu vesileyle yığınak olmaktadır. Dolayısıyla da han tıpkı bir aile babası gibi halka karşı koruyuculuk ve kollayıcılık görevini yerine getirmektedir. Ancak bu babalık vazifesi yerine tam anlamıyla getirilmediğinde Taş Oğuz’un İç Oğuz'a Asi Olup Beyrek Öldüğü Boy'da olduğu gibi isyan ve kargaşaya mahal verebilir.

Oğuz’un ihtiras ve ideolojisi bütün dünyayı kendi hâkimiyeti altına almaktır (Kaplan, 2001: s. 28). Cihan hâkimiyetine soyunacak olan Oğuz Kağan da Bilge Kağan’ın amcası gibi halkını gözetmek zorundadır. Oğuz toy sırasında etrafındakilere asıl niyetini açıllayarak onları cihan hâkimiyeti ülküsüne yönlendirir: 
Ben sizlere oldum Kağan; alalım yay ile kalkan; nişan olsun bize buyan; kurt olsun bize uran; demir kargı olsun orman; Av yerinde yürüsün kulan; daha deniz daha müren; güneş bayrak gök kurıkan (Bang ve Rahmeti, 1936: 17).

Daha sonra da her yere elçilerle tebliğler göndererek herkesin kağanlığını tanımasını ister:

Ben Uygurların kağanıyım ve yeryüzünün dört köşesinin kağanı olsam gerektir. Sizden itaat dilerim. Kim benim emirlerime baş eğerse, hediyelerini kabul ederek onu dost edinirim. Kim baş eğmezse gazaba gelirim; düşman sayarak, ona karşı asker çıkarır ve derhal baskın yapıp onu astırır ve yok ettirtirim (Bang ve Rahmeti, 1936: 17).

Amaç sadece ülkelerin kendilerine tabi olarak vergi vermesini sağlamak ve üstünlüklerinin tanınmasıdır. Bu sayede halkın refahı artacaktır. Oğuz'un bu isteklerini yerine getiren ülkelere sefer düzenlemeye hiç gerek yoktur ama bu üstünlüğü reddederek vergi vermeyi kabul etmeyenleri gazap beklemektedir. Bu anlayış ve tutuma neden olan yukarıda değindiğimiz gibi eski Türklerin kendileri ve Kağanları ile ilgili tasavvurlarından ileri gelmektedir. Kendisini dünyanın merkezine koyan Türkler ve onların Kağanı, Tanrı nizamını yayarak var olma mücadelelerini başarıya ulaştırmak niyetindedir. Dolayısıyla da etrafları kalabalık düşmanlarla çevrilidir. Sayısal azlıklarını da savaşçı niteliklerini geliştirerek ve sürekli hareket ederek telafi etmek mümkündür (Göka, 2011: 110). Türk halkı, tabiatla ve çevreyi kuşatmış çok sayıda düşmanla baş edebilmek, dirlik ve düzen kavgasını kazanabilmek için olanca dikkatini savaş ve töre üzerine yoğunlaştırmıştır (Göka, 2006: 191). Gök Tanrının kendilerine verdiği bu görevi ancak bu şekilde gerçekleştirilebilirler. Dolayısıyla Oğuz Kağan'ın yukarıda naklettiğimiz sözleri tipik göçerevli Türk mantığıdır ve bu anlayışı özetleyecek üç sözcük vardır: sürü, av, akın. Bu üç kelime hem göçebe toplumunu hem de bu toplumun ideal tipini karakterize eder (Kaplan, 2004: 14). Sürülerini büyütmek, yeni avlaklarda yeni avlar bulmak ve bunlar için de akın etmek isteyen ruha sahip bir topluma da ancak Oğuz gibi biri kağanlık/liderlik edebilir. Çünkü grubun/toplumun her kesimini uymaya mecbur etmede en önemli etken, sosyal normları gözeten örnek tiplerdir (Arkonaç, 2001: 225).

Daha önce de belirttiğimiz gibi Oğuz karizmatik bir lider oluşunun gereğini yerine getirmekle yükümlüdür. Lider, burada söz konusu olan atlı göçebe toplumun yukarıda değindiğimiz ihtiyaçlarına cevap vermek zorundadır. Karizmatik lider bu şekilde toplumun ihtiyaçlarını hissetme yeteneğine sahip olduğunda kitleler onun özelliğini fark eder ve grup arzusunu ona bağlar, dolayısıyla, kitle neyi hak ediyorsa lider de ona göre şekillenmektedir (Göka, 2009: 82). Sosyal psikolojide Oğuz Kağan'ın liderlik tutumu "ortam yaklaşımı" içerisinde değerlendirilmektedir. Buna göre grubun başarısında liderin önemli bir rolü vardır. Belli bir çerçevede en etkili lider, o çerçeve içerisinde grubunu hedeflerine ulaştırmak üzere en iyi şekilde donatılmış kişidir. Ortam değiştikçe farklı tipte liderlik özelliklerine ihtiyaç duyulur (Arkonaç, 2001: 291). Oğuz Kağan da savaş dışında halkına karşı daha önce değindiğimiz gibi babalık vazifesini yerine getirmekte, gerektiğinde savaş için tek vücut haline getirip örgütlemekte ve gerektiğinde savaş sırasında orduya Bozkurt'un arkasında liderlik etmekte, dolayısıyla da her ortam için değişik tipte liderlik özellikleri sergilemektedir.

Oğuz’un yukarıda aktardığımız tebliğine benzer bir anlayışı Divanü Lügati’t-Türk’te de görmek mümkündür:

Tanrının devlet güneşini Türk burçlarında doğurmuş olduğunu ve onların milkleri üzerinde göklerin bütün teğrelerini döndürmüş bulunduğunu gördüm. Tanrı onlara Türk adını verdi ve onları yeryüzünde ilbay kıldı. Zamanımızın hakanlarını onlardan çıkardı; dünya milletlerinin idare yularını onların ellerine verdi; onları herkese üstün eyledi; kendilerini hak üzere kuvvetlendirdi (Kaşgarlı, 2006: 3). 
$\mathrm{Bu}$ anlayışa göre hareket eden Oğuz halkını böyle bir amaç uğrunda birleştirip bütünleştirecek anlayışa ve güce sahiptir. Bunu da karşılaştığı birbirinden zor engelleri teker teker aşarak göstermiştir. Tanrı nizamını yeryüzüne yaymak için savaşan Oğuz’un karşılaştığı büyük zorluklarda Tanrı ona doğrudan yardımını göndermiştir. Urum Kağan ile çarpışmak üzere yola çıkan Oğuz Kağan kırk günün ardından "Muz Tag”a gelir ve buraya çadırını kurdurur:

Tan ağarınca Oğuz Kağan'ın çadırına güneş gibi bir ışık girdi. O ışıktan gök tüylü ve gök yeleli büyük bir erkek kurt çıtı Bu kurt Oğuz Kağan'a hitap etti: Ey Ŏguz sen Urum üzerine yürümek istiyosun; ey Oğuz ben senin önünde yürümek istiyorum dedi. Ondan sonra Oğuz çadırını dürdürdü ve gitti. Gördü ki askerin önünde gök tüylü ve gök yeleli büyük bir erkek kurt yürümektedir ve kurdun ardı sira ordu gelmektedir (Bang ve Rahmeti, 1936: 17).

Kurt Oğuz’u ve orduyu savaş yerine kadar getirir ve ardından çarpışma olur ve büyük bir zafer kazanılır. Oğuz’u zafere yürütense doğrudan doğruya Tanrının rehberliğidir. Onun rehberliği Oğuz’a bir kere daha yardım edecek ve ona yine yol gösterecektir. Oğuz Tanrının yardımıyla halkına liderlik ederek onları sayısız zafere ve ganimete götürür.

Oğuz'un liderlik vasfında öne çıkan bir diğer nokta ise onun bugün varlığını bildiğimiz pek çok Türk boyunun ad koyucusu olarak ortaya çıkmasıdır. Oğuz’un bu Türk boylarına -Karluk, Kanglı, Kıpçak- ad verişi bir bakıma -tam anlamıyla Tanrısal türden bir yaratış olamasa da- bir yaratıştır ve Tanrı nizamının sağlayıcılığı noktasında Oğuz’un bir elçilik görevi üstlenişidir. Oğuz’un böyle bir işlevi yerine getiriyor oluşu da şüphesiz Tanrısallı̆̆nın ve ilk ata - medeni kahraman gibi bir hüviyete bürünmüş oluşunun göstergesidir. Nitekim medeni kahraman da tanrısallığı insanoğluna indiren ve güç, akıl, sihir ve askeri hüneri bünyesinde birleştirebilen bir figür olarak görür (İbrayev, 1998: 254).

Reşideddin Oğuznamesinde de Oğuz Kağan bu sefer halkını gaza ideolojisi ile cihan hâkimiyeti ülküsüne götürmektedir. Ancak burada Oğuz'un seferlerini daha detaylı olarak inceleme şansına sahibiz. Oğuz bir taraftan savaşırken diğer taraftan halkının ve fethettiği topraklardaki yeni tebaasının dirlik düzenini sağlamak için kanun koyuculuk rolünü de üstlenir ve bu sefer de İslami anlamda Tanrı nizamının yayıcılığını yapar.

Oğuz Kağan babası ve amcalarıyla yetmiş beş yıl süren savaşın ardından kağanlığını pekiştirir ve az önce yukarıda değindiğimiz ad koyuculuk görevini yerine getirerek kendisine uyanlara "Uygur" adını, savaştan toplanacak ve hayvanların sırtına yüklenemeyecek kadar çok olan ganimet için araba yapan levazımatçısına da "Kanglı" adını verir. Oğuz'un yapılan işlere uygun düşen bu adları veriş nedenleri düşünülecek olursa onun cihangirlik hazırlığı yaptığı anlaşılacaktır. Bütün bunlara ek olarak Oğuz bu harekete girişmeden önce yurdunu savunmasız bırakmamak ve seferlerde rahat edebilmek için etrafındakilerle anlaşmalarını da yenileyerek arkasını sağlama alır. Oğuz’un bu hareketi akıllıca adımlar atarak halkını tehlikeden korumayı amaçlayan ve gereksiz maceralardan kaçınan bir lider portresi çizmektedir. Lider olan kişi, belirli bir sorunun çözümünde ya da ulaşılmak istenen bir hedefin gerektirdiği bir nitelikte diğerlerinden üstün olan kişidir (Şerif ve Şerif, 1996: 211). Oğuz da karşllaşllan sorunlara getirdiği çözümler ve ileride karşısına çıkabilecek muhtemel sorunlara dair aldığı önlemlerle bu üstünlüğünü pekiştirmektedir.

Oğuz bir lider olarak ihaneti asla affetmeyen bir portre çizmektedir çünkü ona karşı gelmek bir bakıma Tanrı nizamına karşı gelmektir. Oğuz, Hint ülkesine yaptığı seferle burayı kendisine bağlar ancak memleketine geri döndüğünde tekrar isyan eden bu ülkenin hükümdarını bu sefer yakalatıp astırarak otoritesini korur. 
Oğuz seferler sırasında oldukça bilinçli hareket etmektedir. Mesela Kuzey ülkelerini zapt etmek için harekete geçmeden önce atlarını Kür-Tak yakınlarında otlatarak semirtmeye ve güçlendirmeye çalışır. Dahası fetihle elde ettiği toprakların halkına da oldukça şefkatli davranarak arkasından çıkabilecek isyanların da önünü almaktadır. Oğuz, Başkurt taraflarına doğru seferini gerçekleştirir ve "bu sıralarda Oğuz herkese şefkat ve sevgi gösterdiğinden yaşlılar ve büyükler kendisine Oğuz Aka adını” (Togan, 1972: 22) verir. Bununla beraber ordusunu hızla sevk ve idare etme düşüncesinde olan Oğuz, ordusunda bulunan hiç kimsenin geride kalmaması ve kalanların da cezalandırılması yönünde bir ferman çıkarır. Oğuz'un ordusunda bulunan ve savaşamayacak durumda olan yaşlılardan biri de Oğuz'un adamlarından Kara Sülük'ün çok bilgili ve tecrübeli bir adam olan babası Yuşı Hoca'dır. Oğluna savaşta pek çok zorluklarla karşılaşacaklarını ve bu zorlukları aşmak için kendisi gibi birine ihtiyaç duyacaklarını bu nedenle kendisini götürmesini söyler ama Kara Sülük babasına "Ey baba Oğuz’un buyruğuna nasıl karşı gelebilirim?” (Togan 1972: 23) diye karşılık verir. Burada Oğuz'un kanun ve nizam koyucu olarak üstlendiği rol daha da belirginleşmektedir. Tanrı'nın gölgesi olarak hükümdar olmuş olan birinin koyduğu kuralı çiğnemek kolay cesaret edilemeyecek bir şeydir ve Kara Sülük de bunun korkusunu yaşamaktadır. Yine de Kara Sülük babasını bir sandığın içine gizleyerek ordunun yanında götürür ki ordu zorluklarla karşılaştığında Kara Sülük babasından gizlice aldığı tavsiyeler sayesinde Oğuz Kağan’a yardımcı olacaktır. Kara Sülük verdiği her tavsiye karşılığında Oğuz Kağan’ın lütuflarına nail olacaktır ve bu nokta da Oğuz’un zekâya ne kadar önem verdiğine delil gösterilebilir.

Oğuz Kağan'ın akıl danışarak liderlik etmesi Türklerin algısına göre kağandan beklenen ve olumlu karşılanan bir davranıştır. Bu bağlamda Türkler arasında "aksakallılar veya yaşlı bilgeler" çok önemlidir. Bilginin ve deneyimin timsali olan bu insanlara danışılmadan hiçbir karar verilmez. Dede Korkut bu anlayışın Türk Dünyasındaki ortak simgesidir. Tanrı onun gönlüne ilham etmiştir ve o Oğuz’un tamam bilicisidir. Ona danışmadan Oğuz içinde hiçbir iş yapılmamaktadır. Türk devlet anlayışının yansıması olup bir siyasetname ve öğüt kitabı hüviyetindeki Yusuf Has Hacip’in “Kutadgu Bilig”i de yöneticilik yapacak kişilere yönelik olarak verdiği öğütler ile bu bağlamda verilebilecek bir başka örnektir. Onun eserinde iyi bir liderin sahip olması gereken niteliklerin belirtilmesi şüphesiz düşünürlerin ve değerli kimselerin düşüncelerine değer vermeyen bir toplumda mümkün olamazdı. Buna ek olarak Oğuz Kağan özelinde onun bir destan kahramanı olduğunu da hesaba katmalıyı. Destanda, kahraman yeni bir mücadele biçimiyle karşılaşır ve varoluşunun sınırlarına ulaşır. Kendisini bir tanrı gibi gösteren şeyleri reddeder ve özellikle insani olan bir kuvveti ve varoluşu kazanır (Greene, 1998: 131). Bunun sonucu olarak da daha önce belirttiğimiz gibi Oğuz Kağan Tanrısal bazı özelliklere sahip olmakla beraber sınırlılığıyla destanın pek çok noktasında karşılaşmakta ve bu gibi durumlarda yardım alarak açığı kapatıp her şeyi kendi başına, bir Tanrı gibi halletmemektedir.

İslami versiyonda da tıpkı Uygur Harfli versiyonda olduğu gibi Tanrısal nizam anlayışının bir sonucu olarak itaat edene zarar verilmemesi düşüncesi hâkimdir. Nitekim aynı düşünce Dede Korkut Kitabı'nda da görülmektedir. Oğuz erleri düşmanlarıyla savaşırken kılıç çekene aman vermez ama aman dileyene kılıç kaldırmaz. Oğuz Kağan da tabi olmayı kabul eden ve aman dileyene kılıç kaldırmayan bir lider görünümü çizmektedir. Derbend üzerine yaptığı sefer sırasında şehri teslim etmeyenler en sonunda teslim olduklarında Oğuz onları huzuruna kabul ederek konuşur:

Onlardan sorun: Biz buraya geleli bu kadar zaman oldu; niçin yanımıza gelmediniz de dikbaşlılık ve isyan yolunu tuttunuz. Onlar cevap olarak dediler ki: Bizim aramızda akıllılar olduğu gibi, divâneleri de vardır. Biz şimdiye kadar bu akılsızların sözüne bakıp gelmedik. Kötü yaptığımızı da biliyorduk. Şimdi akıllı insanlar bizim dikkatimizi çektiler ve öğüt verdiler. Böylece ne yapacağımız aydınlandı. İtaat etmenin gerekli olduğunu bildik ve kulluğuna yüz sürdük. Oğuz şöyle buyurdu: Mâdem ki, suçunuzu böyle itiraf ettiniz, ben de günahınızı bağışladım (Togan, 1972: 28). 
Oğuz’un itaat altına alınanlara yönelik koruyucu politikasına başka örnekler de mevcuttur. Oğuz altı oğlunu Tekür Han üzerine gönderir ama Tekür tabi olmayı kabul etmeyerek savaşmayı seçer. Oğuz’un oğulları Tekür Han’ı yenerler ve kaçan Tekür'ü şehre kadar kovalarlar ama babalarının isteği üzerine şehirden çıkarak şehre yakın bir yerde beklerler. Tekür’ü babalarına yollayarak ona bir de haber gönderirler:

Eğer tekfuru öldürmek niyetinde iseniz bize emredin ülkeyi yağma edip mal ve hazine gönderelim; buna dair bir işaret buyurun kafi. Yok eğer bağışlayarak günah ve kanından vazgeçerseniz, onu ülkesinin başına gönderin. Hükümdarlı̆̆ı ona vermek isterseniz, mal ve hazine vergisini tayin edip onu geri gönderin. Böylece biz halkın kalbini kazanacă̆ız; kulluğa yüz süreceğiz (Togan, 1972: 34).

Oğuz’un oğullarının babalarına gönderdikleri bu mesaj Oğuz’un tabi olan halklara yönelik izlediği politikanın nedenini ve amacını açıça göstermektedir. Oğuz bu politika sayesinde bir lider olarak halkının gözünde büyüyecektir. Ayrıca Oğuz’un bir diğer amacı da emir komuta konusunda oğullarının ne derece dirayetli oluşlarını ölçmektir. Oğuz, Tekür Han'a ülkesinin yağma edilip edilmediğini sorar ve emrine uyulup yağma edilmediğini öğrendiğinde çok sevinir: Ellerini göğsüne koyup yüzünü Tanrıya döndürdü ve çocuklarının sözünden çıkmadıklarına ve onların kabiliyetleriyle babalarının yerine geçmeye muktedir oluşlarına şükretti (Togan, 1972: 34). Böylelikle Oğuz, oğullarının kendi yerine geçmeye layık olup olmadıklarını sınamış olur ve oğullarının bu başarısı onu mutlu eder.

Oğuz'un bir lider olarak öne çıkmasını sağlayan bir diğer nokta ise onun inançlı bir insan olmasında gizlenmiştir. Uygur harfli metinde Oğuz Tanrı'ya yalvarırken gökyüzünden ona ilk eşi gönderilir. Reşideddin Oğuznamesinde ise Dımaşk taraflarında bulunduğu sırada Mekke ve Medine'ye adam gönderen Oğuz oralardan birer avuç toprak ister ve daha sonra bu toprağı vücuduna sürüp oğullarına ve beylerine şöyle seslenir: "Âdem topraktan yaratılmıştı ve sonunda toprak oldu. Biz de hepimiz toprak olacağız. İnsan ne kadar güçlü olursa olsun bunu unutmamalı ve iyilik yapmalı, kötülük değil” (Togan, 1972: 41). İşte Oğuz’un oğullarına ve beylerine verdiği bu mesaj hem onu lider yapan düşünce yapısını hem de onu lider olarak benimseyen Türklerin bir liderde neleri aradıklarını göstermektedir.

\section{4. İktidarın soya aktarımı ya da istikrar}

Tanrı’ın verdiği kut ile Kağan olmak ve Tanrı nizamını yaymak için doğan Oğuz Kağan bu hedefini gerçekleştirdikten sonra kurduğu düzenin devamını ve korunmasını sağlamak için oğullarını yerine geçirecektir. Uygur harfli metinde Oğuz'un annesinin gözlerinin ışıkla parlaması sonucu Tanrı'nın kutu ile doğduğuna değinmiştik. Bu kut aynı şekilde Oğuz’un gökten inen ve ağaç kovuğundan gelen iki eşinin çocuklarını doğururken yine gözlerinin parlaması yoluyla çocuklara da geçmiştir. Böylelikle bir bakıma babadan oğula geçen kutla birlikte hükümdarlık ve kurulu düzenin koruyuculuğu da geçmektedir. Burada, Türklerin göçebe ruhlarının bir üretimi olarak kurulu düzenin aktarımı ve muhafazasından doğan "devlet-i ebed müddet" anlayışı söz konusudur. Türkler bozkır medeniyeti gibi yaşamanın son derece zor olduğu ortamda bir var kalma mücadelesi vermişlerdir. Bu mücadele içinde bir yandan etrafındakilerle savaşırken diğer yandan da onlarla ticaret yapmak zorunda kalmışlardır. Dolayısıyla da düzenin düzgün bir şekilde işleyebilmesi için her türlü kural ve nizamın katı bir şekilde ve muhafazakâr bir çizgide sürdürüldüğü bir gelenekçilik devlet anlayışında hâkim olmuştur. Sosyal ve iktisadi alandaki her türlü ilişkiyi ve dengeyi de bu anlayışla muhafaza etmişlerdir (Göka, 2010: 175-178).

Oğuz pek çok sefer yapar ve dostlarını güldürüp düşmanlarını ağlatır. Sayısız ganimet ve eşyayla yurduna geri döner. Oğuz'un veziri olan Uluğ Türük bir gün rüyasında bir altın yay ve üç gümüş ok görür. Altın yay doğudan batıya doğru uzanırken, üç gümüsş ok da kuzeye doğru uzanmaktadır. Uluğ Türük bu 
rüyayı hemen Oğuz Kağan’a iletir: “Ey Kağanım, senin ömrün hoş olsun: ey kağanım senin hayatın hoş olsun. Gök Tanrı düşümde gördüğümü hakikate çıkarsın. Tanrı bütün dünyayı senin uruğuna bağışlasın!” (Bang ve Rahmeti, 1936: 29). Uluğ Türük’ün rüyayı yorumlayışı Gök Tanrı'nın yardımıyla Oğuz'un bıraktığı mirasın daha da büyüyebileceği yönündedir. Oğuz da bunu anlamak için oğullarını sınar ve onları ava gönderir. Eğer çocuklar gerçekten kağanlık ve cihan hâkimiyeti ülküsünü gerçekleştirebilecek düzeydeyse Gök Tanrı onların karşısına altın yay ve üç oku çıkaracaktır. Nitekim Oğuz’un düşündüğü de gerçekleşecektir. Oğuz’un ilk eşinden doğan oğulları Kün, Ay ve Yultuz Hanlar babaları tarafından doğuya gönderilirler. Pek çok av avladıktan sonra çocuklar bir altın yay bularak bunu babalarına verirler. Oğuz Kağan bunu görünce sevinir ve "Ey büyük oğullarım yay sizlerin olsun; yay gibi okları göğe atın” (Bang ve Rahmeti 1936: 31) der. Oğuz’un ikinci eşinden doğan Kök, Tağ ve Tengiz hanlar da yine babaları tarafından gönderildikleri batı yönünde pek çok av avladıktan sonra üç gümüş ok bularak geri dönerler. Çocuklar bu okları babalarına verirler ve Oğuz yine sevinerek üç oku oğulları arasında bölüştürerek "Ey küçük oğullarım, oklar sizlerin olsun. Yay oku attı; sizler de ok gibi olun" (Bang ve Rahmeti, 1936: 31) der.

Oğuz'un oğullarına yay ve okları paylaştırırken söylediklerinin üzerinde durmak gerekmektedir. Oğuz'un Kün, Ay ve Yultuz'u yayı bulması için doğuya göndermesi ve onlara yayı teslim ederken "yay gibi okları göğe" atın demesi sadece hâkimiyeti oğullarına bırakmanın bir aşaması değildir. Oğuz aslında oğullarına bir devlet ve teşkilat anlayışını bırakmaktadır. Eski Türk devlet anlayışına göre kutsal sayılan doğu tarafında kağan ve yönetici tabaka bulunur ve devletin batısı doğuya tabi olarak hareket etmektedir. Zaten Oğuz'un Kök, Tağ ve Tengiz arasında okları üleştirirken "yay oku attı siz de ok gibi olun” demesi bu anlayışın göstergesidir. Bir başka deyişle yayın oku yönlendirdiği gibi doğuda oturacak olan Kün, Ay ve Yultuz yay sahibi olarak, okların sahibi olan ve batıya yerleşecek olan kardeşleri Kök, Tağ ve Tengiz’i oklar gibi yönlendireceklerdir. Yani devlet doğudan yönetilecek ve batı, doğuya tabi olarak hareket edecektir.

Oğuz Kağan son bir toy düzenleyerek ülkeyi oğulları arasında kesin olarak bölüştürür ve bu zamana kadar yürüttüğü fetih hareketlerinin amacını ve nedenini de ortaya koyar: Ey oğullarım, ben çok aştım; çok vuruşmalar gördüm; çok kargı ve çok ok attım; atla çok yürüdüm; düşmanları ağlattım; dostlarımı güldürdüm. Ben Gök Tanrı'ya borcumu ödedim. Şimdi yurdumu size veriyorum (Bang ve Rahmeti, 1936: 33). Burada da görüldüğü gibi Oğuz Kağan Tanrı nizamını yeryüzüne yaymış ve onun verdiği kut ile oturduğu tahttan fetihler yapıp borcunu ödeyerek inmiştir ve şimdi de bu görevi oğullarına devretmiştir.

Reşideddin Oğuznamesinde de Oğuz Kağan'ın tahtını oğullarına bırakışı Uygur harfli versiyon ile büyük benzerlikler taşımaktadır. Tam olarak elli yıl boyunca seferler düzenlediği için yurdundan ayrı kalan Oğuz Kağan bu uzun fütuhat hareketinin ardından yurduna geri döner. Oğuz, tıpkı Uygur Harfli metinde olduğu gibi geri dönüşünün şerefine doksan bin koç ve dokuz yüz kısrak kestirdiği büyük bir toy düzenletir. Ardından da bir av düzenlenir. Oğuz'un altı oğlu bu av sırasında bir yay ve üç ok bularak bunu babalarına verirler. Babaları da yayı üçe bölerek büyük oğulları arasında paylaştırır ve kırılıp bozulmuş bir yay sahibi olduklarından onların soyundan gelenlerin "Bozok" adı ile anılmasını diler. Oğuz üç oku da küçük oğulları arasında bölüştürerek onların soyundan gelenlerin de "Üç Ok" olarak adlandırılmasını ister. Oğuz yaptığı bu taksimata uygun olarak herkesin ordu içerisindeki yerini ve rütbesini bilmesi gerektiğini belirterek yay verdiklerinin daha üstte yer alarak sağ kanadı, ok verdiklerinin de daha alt kademe de yer alarak sol kanadı teşkil edeceğini söyler. Oğuz bunun nedenini şöyle açıklar: Zira yay padişah gibi hükmeder; ok ise ona tabi bir elçidir (Togan, 1972: 48). Oğuz ülkeyi de bu düzene uygun olarak paylaştırır. Dolayısıyla ülke kutsal olan ve doğuya tekabül eden sağ kanattan 
yönetilecek, sol ise ona tabi olacaktır. Oğuz'un burada vermiş olduğu açıklama ve paylaşım sistemi Oğuz'ların tarihi vesikalardan da takip edebildiğimiz Bozok ve Üç ok şeklinde iki kol halindeki teşkilatlanışlarının kökenini ortaya koymaktadır. Oğuz bu teşkilat yapısını ve devlet düzenini oğullarına emanet eder ve bin yll yaşadıktan sonra vefat eder.

\section{Sonuç}

Oğuz Kağan tarafından destan boyunca sergilenen bütün eylemler aslında onu yaratan toplumun yaşam şartlarının ve buna bağlı beklentilerinin zorunlu kıldığı eylemlerdir. Oğuz Kağan, Atlı-göçebe bir toplumun bir liderden/kağandan beklentilerini ve onu kağanlığa taşıyan özellikleri en ideal haliyle kendisinde toplamış bir şahsiyettir.

Kağan olacak kişi Tanrısal bir kökene sahip olmalıdır. Eski Türklerin deyimiyle kağan tanrıdan kağanlık yapmak için "kut" almış olmalıdır. Aldığı kut onu Tanrı nizamının yayıcısı yapacak ve kağanın cihan hâkimiyeti ülküsünü gerçekleştirmesini sağlayacaktır. Reşideddin Oğuznamesinde görüldüğü gibi bu durum İslamiyet'le birlikte Oğuz Kağan'ın Nuh Peygambere kadar giden kutsal bir soya sahip olmasına dönüşmüştür.

Kağan olacak kişi Tanrısal bir kökene sahip olduğu gibi fiziksel açıdan da yeterliliğe sahip olmalıdır. Güç ve kutsallı̆̆ın birleşimi otoriteyi beraberinde getirecektir. Oğuz Kağan doğuşundan itibaren hızlı bir gelişim göstermiş ve adeta ileride girişeceği fetih hareketleri için baştan ayağa donatılmıştır. Reşideddin Oğuznamesinde ise Oğuz'un çok dindar bir Müslüman olması nedeniyle “Allah'ın nurlu feyzi” kendisine erişmiş ve bu nedenle Oğuz ok atma, kılıç ve kargı kullanmada nam salacak kadar ustalaşmıştır.

Oğuz'un kağan olduğu toplum atlı-göçebedir ve bu toplumun hayatında hâkim olan üç unsur sürü, av ve akındır. Oğuz Kağan bu toplumun ihtiyaçlarını gözetmek zorundadır. Onun bu davranışları sergilemesinde esas nokta destanı yaratan zihniyetin normatif bir eğilimi gözetmesinde yatmaktadır. Lider olacak kişi sosyal normları gözetmek zorundadır. O nedenle Oğuz ilk olarak at sürülerini güden bir çoban kimliğiyle de destanda görünür ve göçebelerin en büyük hazinesi olan at sürülerine musallat olan canavarı öldürerek topluma dirlik verir.

Kağan olacak kişi fiziksel gücün yanında zekâya da sahip olmalıdır. Nitekim Oğuz’un gergedanı yenerken zekâsını kullanması buna bir örnektir. Reşideddin Oğuznamesinde ise Oğuz karşılaştığı pek çok engeli ve zorluğu ordusunda yer alan Kara Sülük'ün babasından gizlice aldığı tavsiyelerle aşacaktır. Dolayısıyla kağan zekâya değer vermeli ve aynı zamanda insanlara liyakatlerine göre muamele eden bir otorite olmalıdır.

Refah sağlayıcı fonksiyonuyla karşımıza çıkan Oğuz, kağan olduğu toplum için yeni avlaklar ve ganimetler elde etmelidir, bu nedenle de seferler düzenlemelidir ki bu aslında Tanrının ona kut vermesinin de bir nedenidir. Reşideddin Oğuznamesi'nde de Oğuz'un uzun ylllar seferlere gidişi anlatılır ki Oğuz’un yurduna geri dönüşü yaklaşı olarak elli yll sürecektir. Oğuz bu iş için seçilmiş kişidir ve Uygur harfli metinde Gök Tanrı'nın onun yardımına gönderdiği erkek kurt bunun göstergesidir. Oğuz’un yapması gereken sadece halkını zafere yürütmektir.

Kağan olan kişi halkını gereksiz tehlikelere sokmamalıdır. Nitekim Oğuz da hem Uygur harfli versiyonda hem de Reşideddin Oğuznamesinde sefere çıkmadan önce tebliğler göndererek kendisine itaat edilmesini diler. Yalnızca itaat etmeyenlere sefer düzenler. 
Seferler düzenlemenin yanında kağan olan kişi yeni fethedilen topraklarla ilgili olarak da düzenlemeler yapmalıdır. Oğuz Kağan hediyeler göndererek ona tabi olanları dost olarak kabul eder. Reşideddin Oğuznamesinde ise Oğuz yeni fethedilen toprakların halkına şefkatle yanaşır ve oraların yağmalanmasını engelleyerek halkın gönlünü kazanır.

Kağan olan kişi Tanrıdan aldığı kutun borcunu Tanrı nizamını yaymak suretiyle ödemelidir. Bu nedenle Oğuz Kağan’ın ideolojisi bütün dünyayı kendi hâkimiyeti altına almaya dayanmaktadır. Oğuz'un fetihleri de bu düzeni sağlamaya yöneliktir.

Kağan gereken düzeni sağladıktan sonra teşkilat yapılanmasını da sağlamalı, kağanlığı layık olanlara devretmelidir. Oğuz'un ülkeyi "Bozok" ve "Üç Ok" anlayışına göre teşkilatlandırması, ordu içindeki konumlarından ülkenin taksimine kadar oğullarına kurulu bir düzen bırakması da bunun göstergesidir. Çünkü bir devletin ayakta kalması, birlik-beraberliği ve devamlılı̆̆ı ancak kanun ve nizamla güvence altına alınabilir. Oğuz da bu düzenlemelerle kendinden sonra da halkının refahını gözetmektedir diyebiliriz.

Türk toplumunun "toplulukçu” bir yapıda olması ve benliğini aşan varlıklara karşı sergilediği bağllık bu kültürün yayılma alanlarında sıklıkla karşımıza çıkmaktadır. Oğuz Kağan'ın sahip olduğu tanrısal köken de onun bir bakıma benliği aşan bir varlık olarak görünmesini sağlamaktadır. Bu nedenle Türklere Kağan olan Oğuz büyük bir kitleyi peşinden sürükleyerek nizam-ı âlemi yeryüzüne yayabilmektedir.

\section{Kaynakça}

Aça, Mehmet (2009), "Ŏguz Kağan ve Aarı Han Destanları Uygarlaşma Süreci Açısından Nasıl Okunabilir”, Milli Folklor, 82, s. 59-75.

Arkonaç, Sibel (2001), Sosyal Psikoloji, İstanbul: Alfa Yayınları.

Bang, W., Rahmeti, G. R. (1936), Oğuz Kă̆an Destanı, İstanbul: Burhaneddin Basımevi.

Bars, Mehmet Emin (2008), “Oğuz Kağan Destanı Üzerine Yapılan Çalışmalar”, Turkish Studies, 3(4), S. 224-240.

Bayat, Fuzuli (2006), Oğuz Destan Dünyası, İstanbul: Ötüken Neşriyat.

Çobanoğlu, Özkul (2011), Türk Dünyası Epik Destan Geleneği, Ankara: Akçă̆ Yayınları.

Duymaz, Ali (2007), “Oğuz Kağan Destanı'ndan Dede Korkut Kitabı'na Kahramanların Beden Tasvirlerinin Sembolik Anlamları Üzerine Değerlendirmeler”, Milli Folklor, 76, s. 50-58.

Ergin, Muharrem (2011), Dede Korkut Kitabı -1, Ankara: Türk Dil Kurumu Yayınları

Güven, Merdan (2003), Oğuz Kağan Destanında Hayvanlar, Milli Folklor, 8(57), s. 82-91.

İbrayev, Şakir (1998), Destanın Yapısı, Ankara: Atatürk Kültür Merkezi Başkanlığı Yayınları.

Göka, Erol (2006), Türk Grup Davranışı, Ankara: Aşina Kitaplar.

Göka, Erol (2009), Türklerde Liderlik ve Fanatizm, İstanbul: Timaş Yayınları.

Göka, Erol (2010), Türkün Göçebe Ruhu, İstanbul: Timaş Yayınları.

Göka, Erol (2011), Türklerin Psikolojisi, İstanbul: Timaş Yayınları.

Greene, Thomas (1998), "Norms of Epic [Epik Normlar]" (Gülay Mirzaoğlu çev.), Milli Folklor, 38, s. 129-135.

Kağıtçıbaşı, Çiğdem (2007), Kültürel Psikoloji: Kültür Bağlamında Aile ve İnsan, İstanbul: Evrim Yayınları. 
Kaplan, Mehmet (2001), “Oğuz Kağan-Oğuz Han Destanı”, Türk Edebiyatı Üzerinde Araştırmalar III, İstanbul: Dergah Yayınları, s.12-28.

Kaplan, Mehmet (2004), “Türk Destanında Alp Tipi”, Türk edebiyat Üzerinde Araştırmalar I, İstanbul: Dergah Yayınları, s.13-21.

Kaşgarlı, Mahmut (2006), Divanü Lügati’t-Türk (B. Atalay, Çev.), Ankara: TDK Yayınları.

Ögel, Bahaeddin (2003), Türk Mitolojisi I.Cilt, Ankara: TTK Yayınları.

Özcan, Tarık (2003), Oğuz Kağan Destanının Kahramanlık Mitosu Bakımından Çözümlenmesi, Milli Folklor, 8(15), s. 76-81.

Roux, Jean Paul (2005), Türklerin ve Moğolların Eski Dini, İstanbul: Kabalcı Yayınları.

Sümer, Faruk (1960), Oğuzlara Ait Destani Mahiyette Eserler, Ankara Üniversitesi DTCF Dergisi, 359455 .

Şerif, M. Şerif, C. (1996), Sosyal Psikolojïye Giriş I, İstanbul: Sosyal Yayınlar.

Tekin, Talat (2003), Orhon Yazıtları, İstanbul: Yıldız.

Temir, Ahmet (2010), Moğollarm Gizli Tarihi (4. Bs), Ankara: TTK Yayınları.

Togan, Zeki Velidi (1972), Ŏguz Destanı, İstanbul: Enderun Yayınları.

Trepalov, Vadim V. (1995), “The Social Status of the Yakut Epic Hero”, Asian Folklore Studies, 54, s. 3548.

Turan, Osman (2003), Türk Cihan Hâkimiyeti Mefkûresi Tarihi: Türk Dünya Nizamının Milli, İslami ve İnsani Esaslarl, İstanbul: Ötüken Yayınları.

Ylldırım, Dursun (1998a), “Köktürklerde Kağanlık Süreci: Kaldırma, Kötürme ve Oturma”, Türk Bitiği, Ankara: Akçağ Yayınları, s. 102-111.

Yıldırım, Dursun (1998b), “Türk Kahramanlık Destanı”, Türk Bitiği, Ankara: Akçağ Yayınları, s. 149155 .

Yıldız, Naciye (1995), Manas Destanı, Ankara: TDK Yayınları. 